\title{
Comparative testing of two alternating current methods for determining wood moisture content in kiln conditions
}

\author{
Hannes Tamme*, Regino Kask, Peeter Muiste and Valdek \\ Tamme
}

Tamme, H., Kask, R., Muiste, P., Tamme, V. 2021. Comparative testing of two alternating current methods for determining wood moisture content in kiln conditions. - Forestry Studies | Metsanduslikud Uurimused 74, $72-87$ ISSN 1406-9954. Journal homepage: http:/ / mi.emu. ee/forestry.studies

\begin{abstract}
Research into the possibility of applying the electric impedance spectrometry (EIS) method and the dielectric capacitance method (DECM) simultaneously above fibre saturation point (FSP) and in harsh kiln conditions has been relatively scarce. In the framework of this research, tests were carried out on the operational reliability of the measuring capacitor (MEC) prototype used for calibrating the DECM in the harsh internal climate $\left(50^{\circ} \mathrm{C}\right.$ and $98 \%$ $\mathrm{RH}$ ) of the kiln. Condensation of water vapor on MEC plates, leakage of MEC insulators and the emergence of static electric charges on MEC plates were studied. Quantitative ranges were found for MEC performance-disrupting effects on the parasitic capacities induced by each effect. The DECM was found to be less reliable than the EIS method for application in harsh kiln conditions. Secondly, under the same test conditions and for the same wood species (birch), the possibilities of the DECM method and the EIS method were comparatively modeled with the predetermined Rozema quality criterion of $\pm 1.75 \% \mathrm{MC}$ for predicting the moisture content (MC) of birch wood above FSP. It was found that, under the same test conditions, the DECM method proved more accurate than the EIS method for predicting birch wood MC above FSP. Based on the tests, it was concluded that DECM can be used in practice by applying a non-destructive method to reliably determine the average moisture content of a wood batch immediately prior to commencing the wood-drying process.
\end{abstract}

Key words: dielectric capacitance method, electric impedance spectroscopy, wood drying.

Authors' address: Chair of Forest Management Planning and Wood Processing Technologies, Institute of Forestry and Rural Engineering, Estonian University of Life Sciences, Kreutzwaldi 5, 51006 Tartu, Estonia; *e-mail: hannes.tamme@student.emu.ee

\section{Introduction}

In drying wood, it is necessary to monitor the moisture content of the wood in order to control the drying process. It is particularly important to reliably determine the average moisture content (MC) of fresh- ly sawn wood prior to commencing the wood-drying process in order to use a simulation program to assess the drying time, energy consumption, risk of cracks developing during the drying process and other changes in wood quality (Salin, 1990; Tamme, 2016).

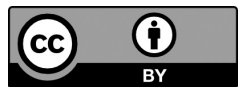

(C) 2021 by the authors. Licensee Estonian University of Life Sciences, Tartu, Estonia. This article is an open access article distributed under the terms and conditions of the Creative Commons Attribution (CC BY) license (http://creativecommons.org/licenses/by/4.0/). 
In practice, the direct current (DC) electric resistance method (Stamm, 1927; Tamme et al., 2012; Uwizeyimana et al., 2020) for determining and monitoring wood moisture content is widely used, as it is an inexpensive and reliable method for use both at room temperature and in harsh kiln conditions (Gann, 2021; Scanntronik, 2021; Brookhuis, 2021; BES Bollmann, 2021; etc.). However, the main disadvantage of the DC resistance method is that the MC readings obtained by this method are not reliable above FSP (ca. more than $30 \% \mathrm{MC}$ ) (ASTM D4444-08, 2008; Tamme, 2016). The alternating current $(\mathrm{AC})$ resistance method has proven approximately $14 \%$ more accurate than the DC method (Casans Berga et al., 2019). The EIS method has been used for determining wood MC gradient (Tiitta et al., 1999). The EIS method was used to monitor wood drying in combination with the acoustic emission (AE) method (Tiitta et al., 2010). Another widely utilized method for determining wood MC is the dielectric capacitance method (DECM) (James et al., 1985). This high-frequency capacitance method has also been called the microwave method. Previous research (Moschler, 2004) used the high-frequency (4-6 GHz) capacitance method to determine the average MC of wood in a kiln, leading to the development of a corresponding prototype calibrated into a moisture meter. In the case of the capacitance method, the prevailing geometry of the measuring capacitor (MEC) is a design with carefully electrically insulated flat parallel plates (Moschler, 2004; Tamme et al., 2019). The advantage of the various technical applications of plate capacitor geometry is the simple calculation formula for electric capacitance (Zuleta, 2005):

$$
C=\varepsilon \varepsilon_{0} A / d
$$

Where $C$ is the capacitance of a parallel plate capacitor, $A$ is the area of one plate in square meters, and $d$ is the distance between the plates in meters. The constant $\varepsilon_{0}$ is the permittivity of vacuum, and $\varepsilon$ is the dielectric constant or relative dielectric permittivity. The dielectric constant $\varepsilon$ depends on the moisture content of the wood placed between the MEC plates. According to formula (1), the electric capacitance $C$ is proportional to the dielectric constant $\varepsilon$, hence the specific name of the method for determining the moisture content of wood - the dielectric capacitance method. For comparison: absolute dry (oven-dry) wood $\varepsilon=4$, and water $\varepsilon=80$ (Welling, 2010).

A flat ring capacitor for measuring wood MC below FSP (e.g., Brookhuis, (2020), FMW moisture indicator, $3.5 \mathrm{MHz}$ operating frequency measured with an oscilloscope) and a flat slit capacitor (9.375 $\mathrm{GHz}$ operating frequency) for measuring wood MC both below FSP and above FSP have also been used (Johansson et al., 2003).

The objective of our research was to test the MEC prototype developed for the paper in harsh conditions similar to those of a kiln in order to assess risks to the reliability of the MEC. The second objective was to use regression analysis to identify the possibilities of the DECM and EIS methods to establish the predetermined accuracy and to make a reliable determination of wood MC above FSP within the EIS operating frequency range of $1 \mathrm{Mz}-10 \mathrm{~Hz}$.

\section{Material and Methods}

The relationship between electric capacitance, the wood impedance modulus and average moisture content above and below FSP (FSP is agreed at $30 \%$ wood moisture content) was explored using a clear birch board with a thickness of $35 \mathrm{~mm}$, width of $150 \mathrm{~mm}$ and length of $470 \mathrm{~mm}$.

The moisture content of the birch wood specimen was varied by means of a specially developed laboratory drying schedule (Tamme et al., 2013). The drying schedule ensured that during the first drying phase (at constant speed), the drying curve decreased linearly and moisture gradients 
in the specimen were minimal.

The average MC of wood was determined by weighing the specimen at various randomly selected times using a precision weight with a resolution of $0.1 \mathrm{~g}$. After weighing the specimen at the same average $\mathrm{MC}$, other necessary measurements were also carried out as quickly as possible, such as measurements of the wood electric capacitance and wood impedance. In the final stage of the tests, the dry weight of the specimen was determined by drying it at $103^{\circ} \mathrm{C}$. The actual moisture content of the specimen (relative to its dry weight) at the moment of weighing was identified according to ISO 3130:1975 (1975) standard.

An improved version of the parallel plate MEC was developed to determine the electric capacitance of wood at different moisture levels above FSP, compared to that used in our previous paper (Tamme et al., 2019); its circuit diagram is shown in Figure 1(a) and the MEC with the measured specimen is shown in the photograph in Figure 1(b).

The cubic measure between the MEC plates was chosen at about $10 \%$ larger than the cubic measure of the specimen. This difference between the cubic measures ensured the necessary slack (tolerance zone) for the specimen when it was replaced between the plates after each weighing. The MEC allowed for the possibility of separate and combined heating of the insulators and plates in the form of a film of water vapor in the climate chamber to study condensation on MEC structural elements and to remove static electric charges of triboelectric origin (Tamme et al., 2019) in the system. Additionally, the developed parallel plate measuring capacitor prototype was tested in conditions similar to kiln climate in the FEUTRON climate chamber (Feutron Klimasimulation $\mathrm{GmbH}, 2021)$. The tests were conducted at a temperature of $50^{\circ} \mathrm{C}$ and at a maximum relative air humidity $(\mathrm{RH})$ of $98 \%$. The purpose of the tests was to check the reliability of the measuring capacitor in the harsh kiln climate and to eliminate the
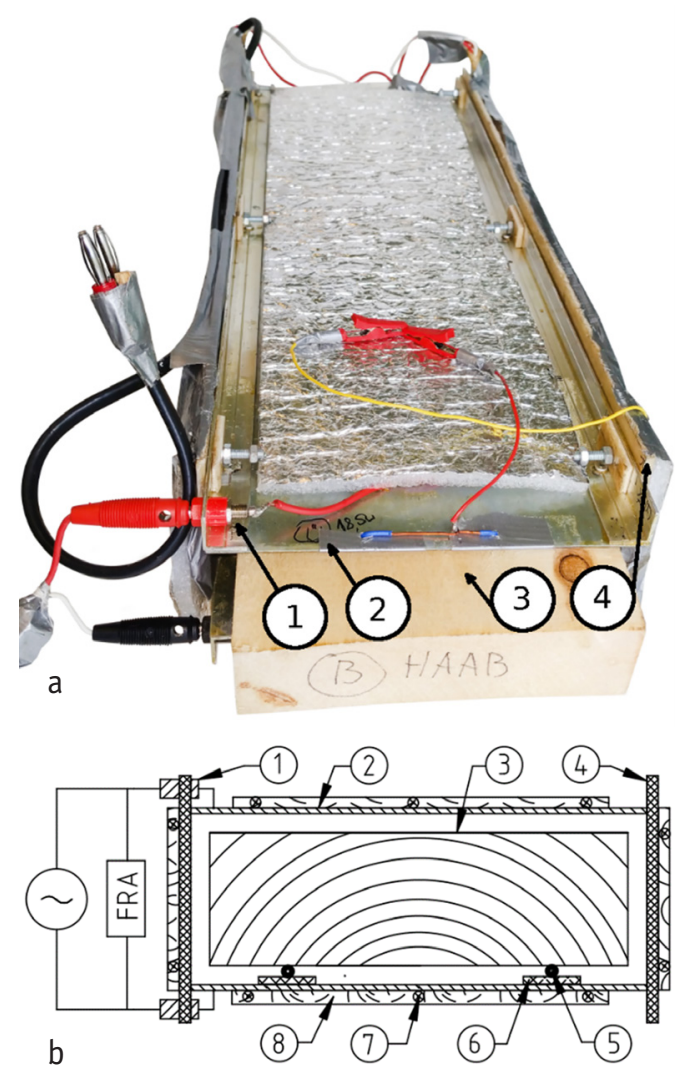

Figure 1. (a) Circuit diagram of the measuring capacitor (MEC) and (b) photograph of the MEC prototype with the tested birch wood specimen. 1 - signal connector, 2 - capacitor plate, 3 - wood specimen, 4 - capacitor insulator, FRA - frequency response analyser, 5 - triboelectric charge collector, 6 - film insulator, 7- heating cable, 8 - heat insulator.

occurrence of water vapor saturation and condensation of humidity on the measuring capacitor plates and insulators.

According to literature (Moschler, 2004), the microwave measuring capacitor prototype with parallel plates was tested at room temperature and at temperatures of $40^{\circ} \mathrm{C}$ and $60^{\circ} \mathrm{C}$. Moschler (2004) contains no data on the relative humidity in the chamber during the tests, which is an important climate parameter. The measurements of electric capacitance present- 
ed in this paper were carried out using the LCR55 (Wavetek Meterman, 2021) capacitance meter (CAM). The LCR55 capacitance meter has an operating frequency of $1,000 \mathrm{~Hz}$ as measured with an oscilloscope.

Wood impedance was measured using stainless steel insulated pin electrodes made by the company Gann (Gann 2021), which were nailed into the wood across the grain at a spacing of $30 \mathrm{~mm}$ (Brookhuis Micro-Electronics, 2009). The nails were driven to a depth of $1 / 3$ of the thickness of the wooden material (Welling, 2010), which is about $12 \mathrm{~mm}$ from the board surface for a $35 \mathrm{~mm}$ board thickness. After each impedance measurement, the electrodes were nailed into the next randomly selected location on the board and at the same depth from the surface of the board. The impedance modulus of the measured AC complex electric resistance was calculated on the basis of impedance spectrometry (EIS) measurement data using EIS standard formulas (Krause, 2003; Tamme et al., 2019). Each time, the impedance modulus was determined when the EIS spectrum phase angle had a minimum (ca. 4 to 5 degrees) value. An AUTOLAB PGSTAT 408N impedance analyser with NOVA 1.8 software was used (Metrohm Autolab, 2021).
Interference with the reliability of the measuring capacitor in conditions similar to harsh kiln climate (that is, imitated in a laboratory climate chamber) was also recorded using impedance spectra and processed with the NOVA 1.8 software using the circle-fit analysis tool. To do so, frequency scanning between $1 \mathrm{MHz}$ and 10 $\mathrm{Hz}$ and the electric sine wave amplitude of $50 \mathrm{mV}$ were applied.

The possible effect of static electricity on the measurements taken by the measuring capacitor was first investigated indirectly using Keithley's model 6517B with an electrometer (Keithley, 2004) and then directly for potentials safe for the instrument (up to $0.9 \mathrm{~V}$ ) using LCR55 (Tamme et al., 2019).

Statistical processing of the test results was based on the principles of a metrology standard ISO 3534-1:1993 (1993) and carried out with software R (R Core Team, 2010), MS Excel and NOVA 1.8. In the case of Student t-distribution and linear regression for the single measurement, the upper and lower tolerance lines (confidence limits) of the regression line are presented in MS Excel at 95\% confidence level as follows (Kiviste, 1999):

$$
\begin{aligned}
& \text { Intercept } \mathrm{b}_{0} \text { lower }=b_{0}-\operatorname{TINV}(\alpha ; n-2) * s_{b 0} \\
& \text { Intercept } \mathrm{b}_{0} \text { upper }=b_{0}+\operatorname{TINV}(\alpha ; n-2) * s_{b 0} \\
& \text { Slope } \mathrm{b}_{1} \text { lower }=b_{1}-\operatorname{TINV}(\alpha ; n-2) * s_{b 1} \\
& \text { Slope } \mathrm{b}_{1} \text { upper }=b_{1}+\operatorname{TINV}(\alpha ; n-2) * s_{b 1}
\end{aligned}
$$

Where $s_{b 0}$ and $s_{b 1}$ are the standard errors of the regression line intercept and slope (Kiviste, 1999).
The following formulas were used to estimate the standard error (SE) and the average root-mean-square error (RMSE) of the regression model: 


$$
\begin{gathered}
S E=\sqrt{\frac{1}{(n-2)} \sum_{i=1}^{n}\left(y_{i}-\hat{y}\right)^{2}} \\
R M S E=\sqrt{\frac{1}{n} \sum_{i=1}^{n}\left(y_{i}-\hat{y}\right)^{2}}
\end{gathered}
$$

The non-parametric KolmogorovSmirnov test and the Shapiro-Wilk test (Tamme et al., 2014) were used in the $\mathrm{R}$ software environment to estimate the reliability of the regression models.

\section{Results and Discussion}

Changes in electric parameters caused by water vapor condensation were measured

Where $y_{i}=$ the estimated values and $\hat{y}=$ using the LCR55 and the EIS method. the actual values.

\section{Effect of water vapor condensation on MEC plates}
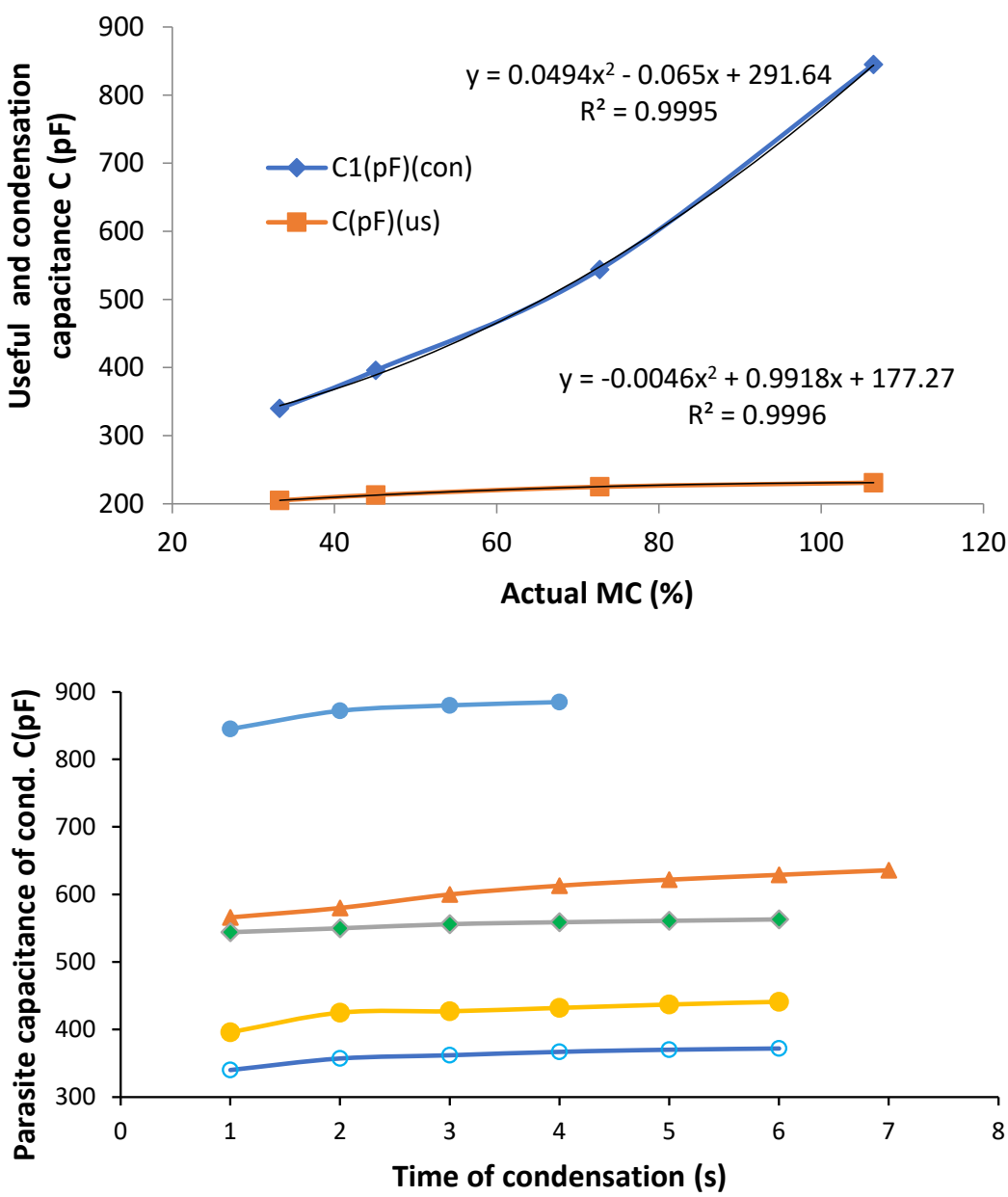

$-106 \% \mathrm{MC} \leftarrow 97 \% \mathrm{MC} \longrightarrow 73 \% \mathrm{MC}-45 \% \mathrm{MC} \multimap 33 \% \mathrm{MC}$
Figure 2.

The dependence of MEC useful capacitance and parasitic capacitance caused by water vapor condensation on MEC plates on the actual average moisture content of wood in the same coordinate grid. The upper curve in the figure represents parasitic capacitance, and the lower, useful capacitance.

\section{Figure 3.}

Increment of parasitic capacitance due to condensation of water vapor on MEC plates at varying wood moisture levels. 
The parasitic capacitance of condensation observed on MEC plates (indicated as $\mathrm{C}_{\text {parasite }}$ in Table 1) and the useful capacitance are shown on the same axis in Figure 2, depending on the average moisture content of wood. The EIS method allowed the development dynamics of the condensation process to be monitored (Figure 4, a) and b)) and the quantitative parameters for the electric capacitance $C_{\text {parasite }}$ to be calculated.

Figure 3 shows the relative time increments of the parasitic capacitance of condensation on the MEC plates at different wood average moisture levels recorded using the capacitance meter (CAM) LCR55. Both the EIS method and the LCR55 show a similar magnitude for the parasitic capacitance on the MEC plates $\left(\mathrm{C}_{\text {parasite }}=660 \mathrm{pF}\right.$ and $\mathrm{C}_{\text {parasite }}=800 \mathrm{pF}$, respectively). Based on Figure 3, it may be concluded that the higher the average MC of wood, the greater the value of parasitic capacitance due to water vapor condensation. Parasitic capacitance of approximately 5 times the useful capacitance may completely obscure the correct useful capacitance measurements under conditions favourable for water vapor condensation.

\section{Leakage effect of MEC insulators}

The leakage effect of the insulators is characterized by the occurrence of parallel resistance of the condensed water film on the insulators in addition to parasitic capacitance, which shunts the resistance of the insulators. The MEC insulator resistance in normal operation is approximately $10 \mathrm{gi}-$ ga-ohms or greater. The circle-fit analysis found that in the initial phase of leakage, the parallel resistance of a leaking insulator is $R p=61 \mathrm{kOhm}$ and its parasitic capacitance is $C_{s}=163 \mathrm{pF}$, whereas $R p=0.78$ $\mathrm{kOhm}$ and $\mathrm{Cs}_{\mathrm{s}}=681 \mathrm{pF}$ in the final phase of the leakage.

\section{MEC static charge effect}

Figure 5 shows the dynamics of electrostatic charge formation when placing the birch
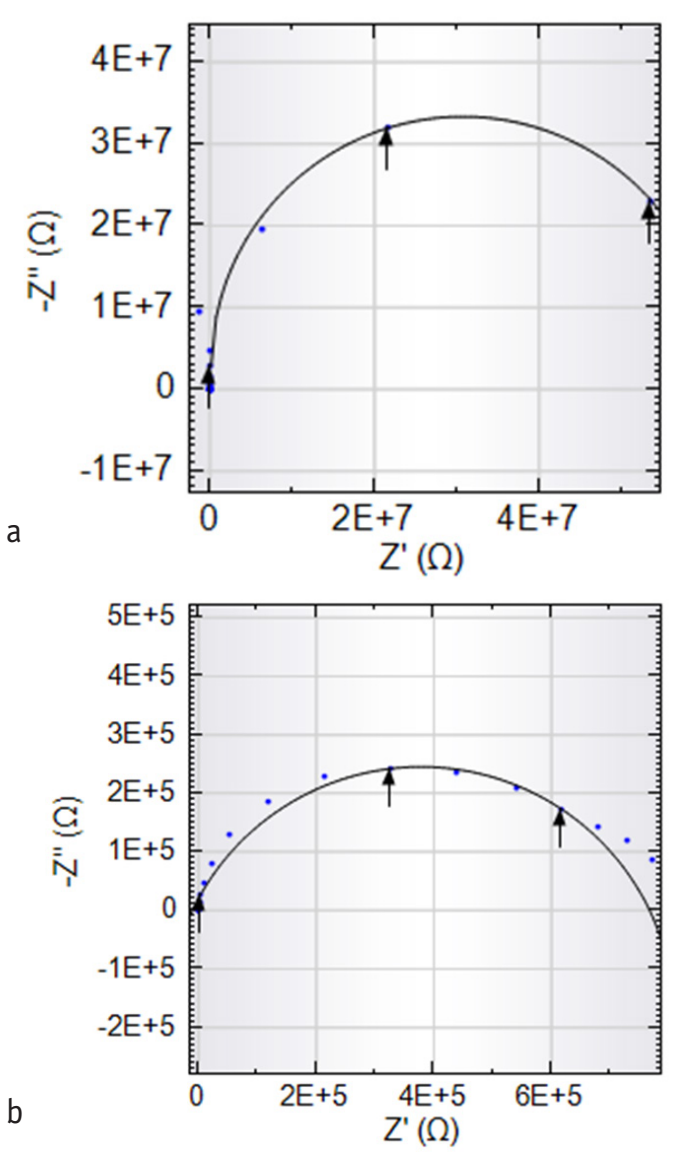

Figure 4. Impedance spectra of leakage of MEC insulators: (a) Start phase of the leakage and (b) End phase of developed leakage.

wood specimen between and removing it from the MEC plates. This procedure was repeated 15 times. A measurement interval of 0.1 seconds was used. In Figure 5, one maximum of impulse voltage generated by static charge corresponds to each cycle of placement and removal of the specimen between the MEC plates. Maximum values (or peaks) with negative potential were predominantly recorded. Because the potential was measured from the electrostatic charge removal system (see Figure 1), the wood itself was oppositely charged; that is, predominantly positive. The potential of electrostatic charges generally decreases when the movement of the specimen in relation to the MEC ceases. However, this 


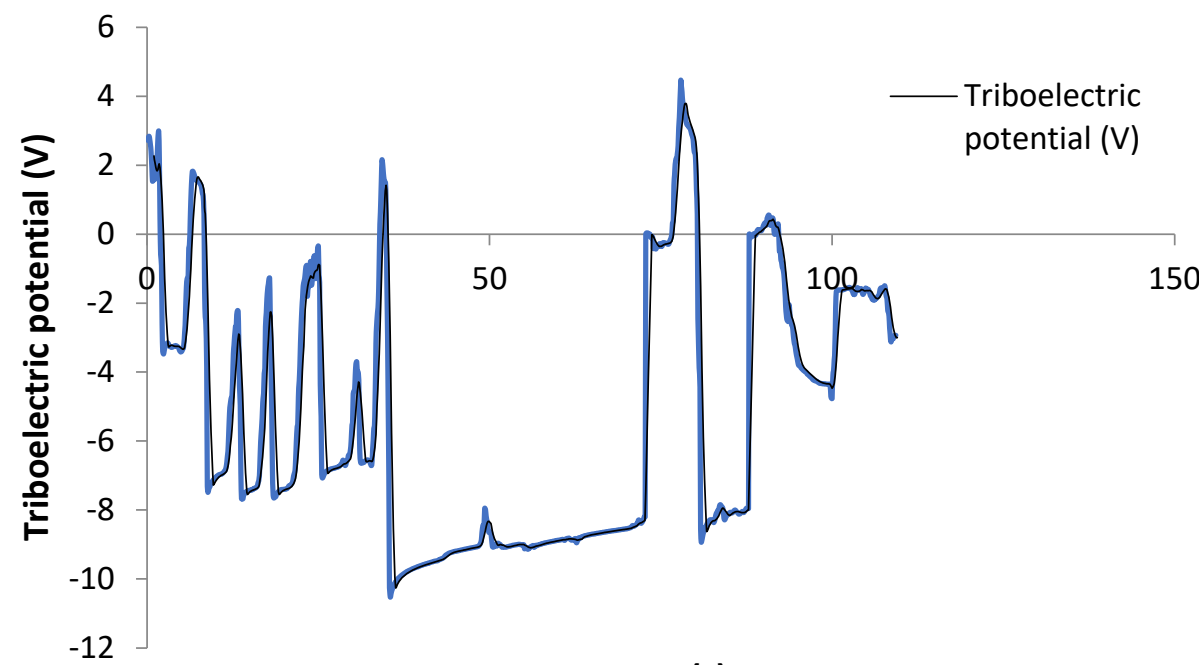

Time (s)

Figure 5. Dynamics of the potential for static electric charges of triboelectric origin when the birch wood specimen is placed between and then removed from the MEC plates.

is not always the case, as Figure 5 shows an exceptional peak where the potential remains high (ca. $10 \mathrm{~V}$ ) for a considerable time (ca. 30 seconds). The triboelectric potential peak may exceed the CAM LCR55 safe input voltage (up to $0.9 \mathrm{~V}$ ) by about 10 times.

\section{MEC temperature effect}

In previous research (Moschler, 2004), the electric capacitance of the measured wood was found to increase slightly with the increase in wood temperature. The same tendency was confirmed in our previous paper (Tamme et al., 2019). In this current study, the measured increase in electric capacitance of MEC with oven-dry wood was from room temperature of $23^{\circ} \mathrm{C}$ to $105^{\circ} \mathrm{C}$ : $121 \mathrm{pF}$ to $124 \mathrm{pF}$. Thus, the effect of temperature on the electric capacitance of oven-dry wood is negligible (only $3 \mathrm{pF}$ ) and may be disregarded in a rough approximation. The minor effect of temperature on the capacitance method is also highlighted in industry guidelines (Welling, 2010). On the basis of the above, it was concluded that due to its low temperature sensitivity, the DECM could be used in practice immediately prior to the start of the wood-drying process by a non-destructive method to reliably determine the average moisture content of the wood batch for the wood drying simulation program.

In addition, an important trend that emerged during testing must be pointed out: namely, condensation effects that obscure the useful capacitance of MEC predominate when the air $\mathrm{RH}$ in the climate chamber is higher than $60 \%$, but electrostatic charges occur often on the MEC when the air $\mathrm{RH}$ in the climate chamber is lower than $60 \%$.

To summarize, the various physical characteristics and effects influencing the electric capacitance of the MEC are presented in Table 1. Based on the data in the bottom row of Table 1 (useful capacitance), it can be concluded that the DECM in the range below FSP $(0-30 \% \mathrm{MC})$ is about 8 times more sensitive per percent of $\mathrm{MC}$ compared to the range above FSP (30\%$105 \% \mathrm{MC})$. 
Table 1. The main physical reliability characteristics of the dielectric capacitance method (DECM) in kiln climate and the corresponding capacitance meter (CAM) response.

\begin{tabular}{|c|c|c|}
\hline Effect, parameter, figure no. & Effect range & CAM response \\
\hline $\begin{array}{l}\text { Condensation of water vapor on MEC } \\
\text { plates, Fig. } 2,3\end{array}$ & $\begin{array}{l}C_{\text {parasite }}=340 \text { to } 845 \mathrm{pF} \\
\mathrm{C}_{\text {parasite }}=681 \mathrm{pF}, \\
\text { determined using EIS method }\end{array}$ & $\begin{array}{l}\text { CAM reading recorded ca. } 5 x \\
\text { and moderately increasing ** }\end{array}$ \\
\hline Leakage of MEC insulators, Fig. 4 & $\begin{array}{l}\mathrm{C}_{\text {parasite }}=163 \text { to } 681 \mathrm{pF} \\
\mathrm{R}_{\text {parallel }}=61 \text { to } 0.778 \mathrm{k} 0 \mathrm{hm}\end{array}$ & Floating of CAM reading \\
\hline $\begin{array}{l}\text { Triboelectric charges on MEC plates, } \\
\text { Fig. } 5\end{array}$ & $U_{\text {static }}=-10.5$ to $4.29 \mathrm{~V}$ & $\begin{array}{l}\text { Floating of CAM reading, } \\
\text { CAM spoilage risk }\end{array}$ \\
\hline $\begin{array}{l}\text { Useful MEC capacitance, } \\
\text { below FSP }(0 . \% \text { to } 30 \%) \\
\text { Useful MEC capacitance, } \\
\text { above FSP ( } 30 \% \text { to } 105 \%)\end{array}$ & $\begin{array}{l}C_{\text {useful }}=121 \text { to } 205 \mathrm{pF} \\
M C=0 \% \text { to } 30 \% \\
C_{\text {useful }}=205 \text { to } 231 \mathrm{pF} \\
M C=30 \% \text { to } 105 \%\end{array}$ & $\begin{array}{l}\text { CAM reading stable and } \\
\text { reliable }\end{array}$ \\
\hline
\end{tabular}

\section{Useful capacitance of MEC and dielectric capacitance modelling}

Useful capacitance is defined as the measured capacitance of MEC with wood, which excludes interfering effects, such as condensation on MEC plates, leakage of MEC insulators and the presence of static charges on MEC plates. Our previous paper (Tamme et al., 2019) indicated that useful capacitance also depends significantly on the selected CAM operating frequency, while being higher in the low frequency range. However, low frequencies proved more sensitive to the effect of water vapor condensation.

For useful capacitance only, it would be reasonable to establish a statistically reliable correlation (generally a linear regression model) between the actual (i.e., determined by weighing) average moisture content of wood and the moisture content predicted by the capacitance method or, in other words, to statistically model the capacitance method. The methodology for modelling the EIS method does not differ from modelling the capacitance method.

Comparatively, the results of modelling the capacitance method and the EIS method are presented in Table 2 and Figures 6, $7,8,9,10,11$.
Formulas in Table 2 and Figure 11, which connect various methods, are presented according to the needs of the wood drying practice. The model RMSE or SE, the $p$-value and the coefficient of determination $R^{2}$ mainly attract theoretical interest. Wood drying practitioners are primarily interested in two issues based on the modelling results: whether a single measurement fall on the $95 \%$ confidence level within the desired measurement precision range, and if not, how many repeated measurements are required in the series of measurements in order to achieve the desired prescribed precision. A series of measurements is defined as a certain number $(k)$ of measurements repeated and arithmetically averaged at close moments in time under the same testing conditions (Brookhuis, 2020; Laaneots \& Mathiesen, 2006). The Rozema quality criterion was used to define the prescribed measurement accuracy, according to which the standard uncertainty of the wood moisture meter reading must be less than or equal to $3.5 \%$ MC (Rozema, 2010). The individual measurement tolerance interval calculated on the Student t-distribution assumption based on formulas 2, 3, 4 and 5 should represent extended uncertainty in metrology 
Table 2. Modelling results of the dielectric capacitance method (DECM) and electric impedance spectrometry (EIS) method. In regression models, the independent $x$-variable is the actual MC (\%), and the dependent $y$-variable is the predicted MC (\%). The predicted single measurement tolerance bands on the $95 \%$ confidence level, $y_{\text {upper }}$ and $y_{\text {lower }}$ are calculated using formulas 2, 3, 4 and 5 . The SE is calculated according to formula 6 . The tolerance interval (TI) is calculated using the formula TI $=y_{\text {upper }}-y_{\text {lower }} . N$ is the number of measurements repeated under the same test conditions and $k$ is the number of measurements averaged per series of measurements (i.e., the averaging period). For models with a series of measurements $(k)$, the identification type shall be "multiple".

\begin{tabular}{|c|c|c|c|c|c|}
\hline $\begin{array}{l}\text { Nobs., } \\
\text { k-period }\end{array}$ & $\begin{array}{l}\text { Method type, } \\
\text { Fig. no. }\end{array}$ & $\begin{array}{l}\text { Equations for predicting single } \\
\text { measurement tolerance bands and TI }\end{array}$ & $\mathrm{R}^{2}$ & $\begin{array}{l}\mathrm{p} \text {-value } \\
\text { and tests* }\end{array}$ & SE \\
\hline$N=63$ & $\begin{array}{l}\text { DECM } \\
\text { (above FSP), Fig. } 6\end{array}$ & $\begin{array}{l}y_{\text {upper }}=1.0131 x+5.9063 \\
y_{\text {lower }}=0.9406 x+0.8399 \\
\mathrm{TI}=0.0728 x+5.075\end{array}$ & 0.97 & $\begin{array}{l}<0.01 \\
\mathrm{~K}-\mathrm{S}\end{array}$ & 4.88 \\
\hline$N=42$ & $\begin{array}{l}\text { DECM } \\
\text { (below FSP), Fig. } 7\end{array}$ & $\begin{array}{l}y_{\text {upper }}=1.0135 x+0.2792 \\
y_{\text {lower }}=0.9788 x-0.1954 \\
\mathrm{TI}=0.0348 x+0.4746\end{array}$ & 0.99 & $\begin{array}{l}<0.01 \\
\mathrm{~K}-\mathrm{S} \\
\mathrm{S}-\mathrm{W}\end{array}$ & 0.61 \\
\hline $\begin{array}{l}N=63 \\
k=16\end{array}$ & $\begin{array}{l}\text { DECM } \\
\text { (above FSP) } \\
\text { (multiple), Fig. } 8\end{array}$ & $\begin{array}{l}y_{\text {upper }}=1.006 x+0.44 \\
y_{\text {lower }}=0.9929 x-0.4163 \\
T I=0.0124 x+0.8775\end{array}$ & 0.99 & $\begin{array}{l}<0.01 \\
\text { K-S } \\
\text { S-W }\end{array}$ & 0.46 \\
\hline$N=63$ & $\begin{array}{l}\text { EIS } \\
\text { (above FSP), Fig. } 9\end{array}$ & $\begin{array}{l}y_{\text {upper }}=0.9448 x+11.196 \\
y_{\text {lower }}=0.787 x+2.41 \\
\mathrm{TI}=0.1622 x+8.135\end{array}$ & 0.87 & $\begin{array}{l}<0.01 \\
\mathrm{~K}-\mathrm{S}\end{array}$ & 5.01 \\
\hline $\begin{array}{l}N=63 \\
k=16\end{array}$ & $\begin{array}{l}\text { EIS } \\
\text { (above FSP) } \\
\text { (multiple), Fig. } 10\end{array}$ & $\begin{array}{l}y_{\text {upper }}=1.0134 x+1.728 \\
y_{\text {lower }}=0.968 x-0.84 \\
T I=0.0365 x+2.836\end{array}$ & 0.99 & $\begin{array}{l}<0.01 \\
\mathrm{~K}-\mathrm{S}\end{array}$ & 0.867 \\
\hline
\end{tabular}

* Kolmogorov-Smirnov (K-S) test and Shapiro-Wilk normality (S-W) test

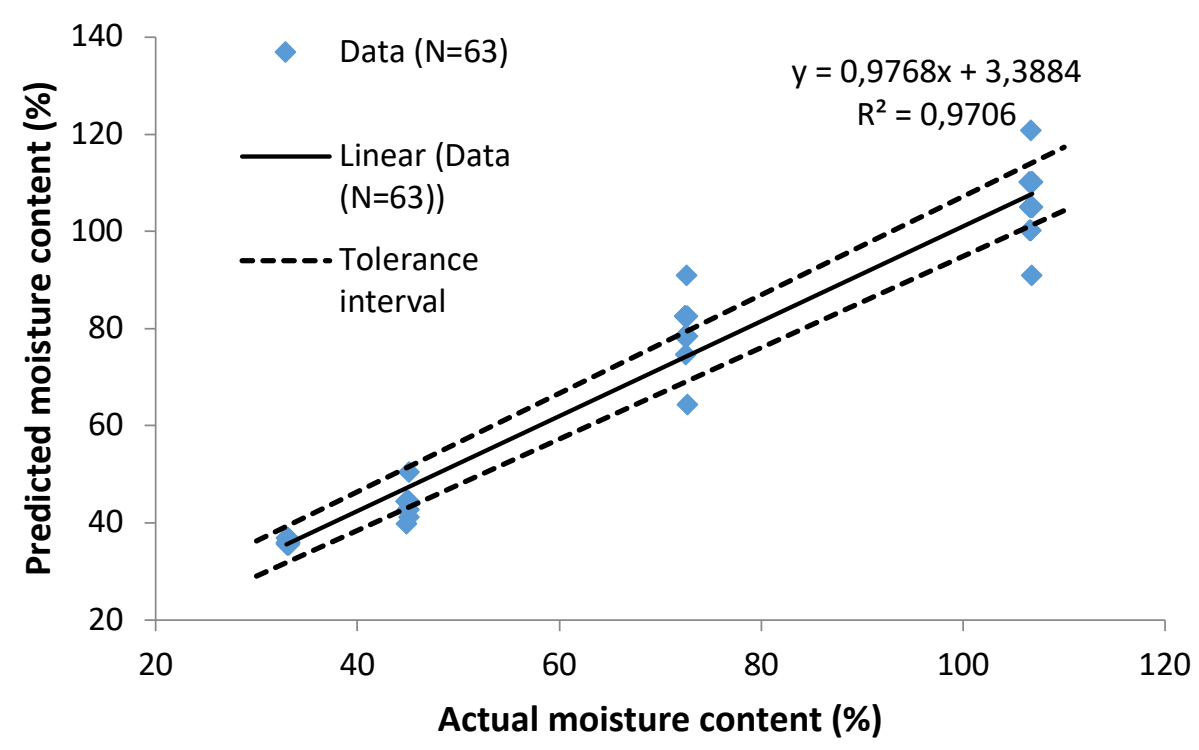

Figure 6. DECM modelling at wood moisture levels above FSP. 


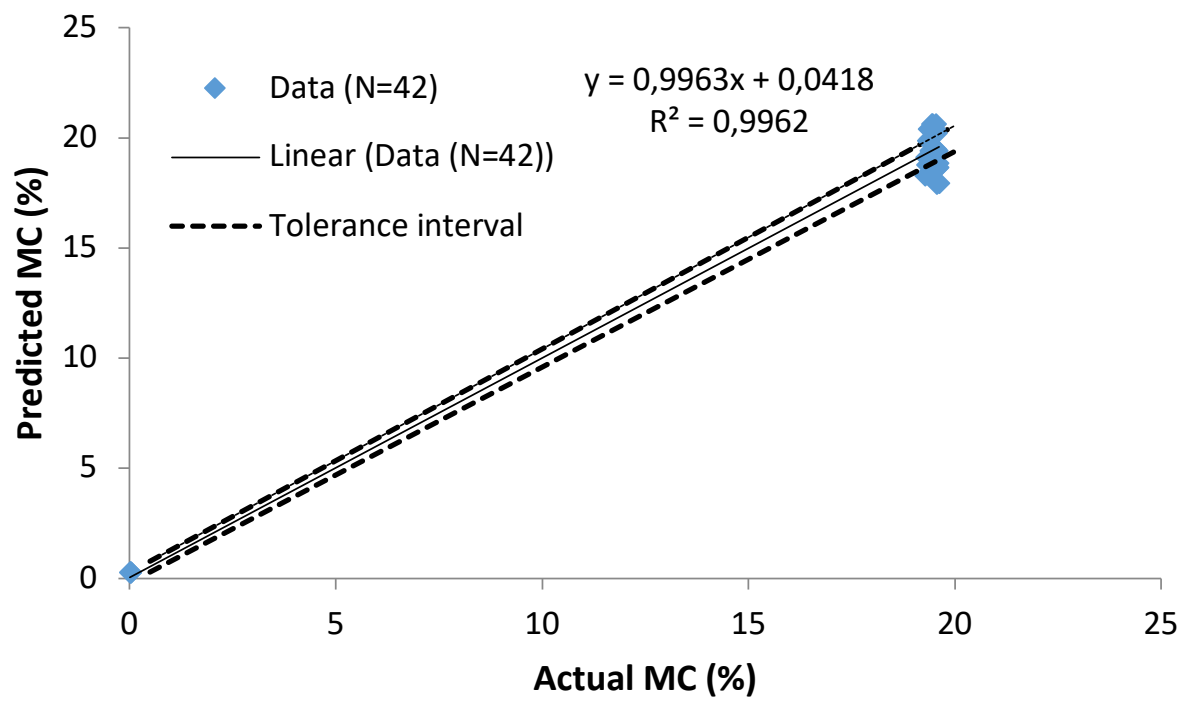

Figure 7. DECM modelling at wood moisture levels below FSP.

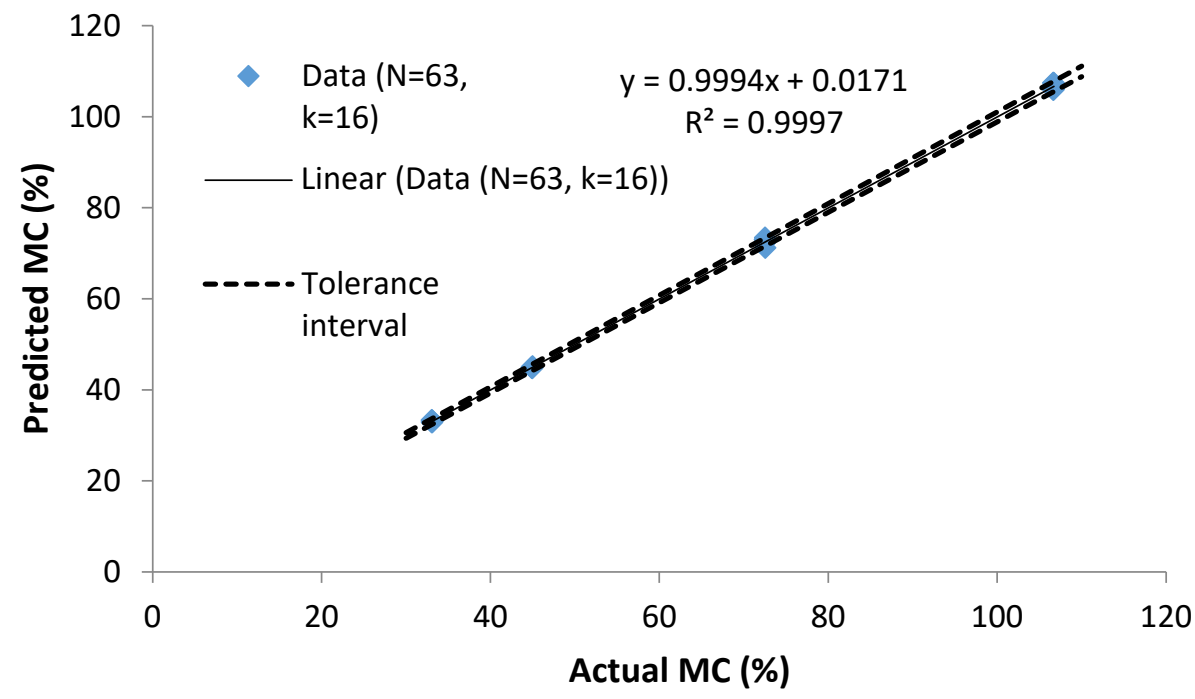

Figure 8. DECM modelling at wood moisture levels above FSP, multiple $(k=16)$ model. 


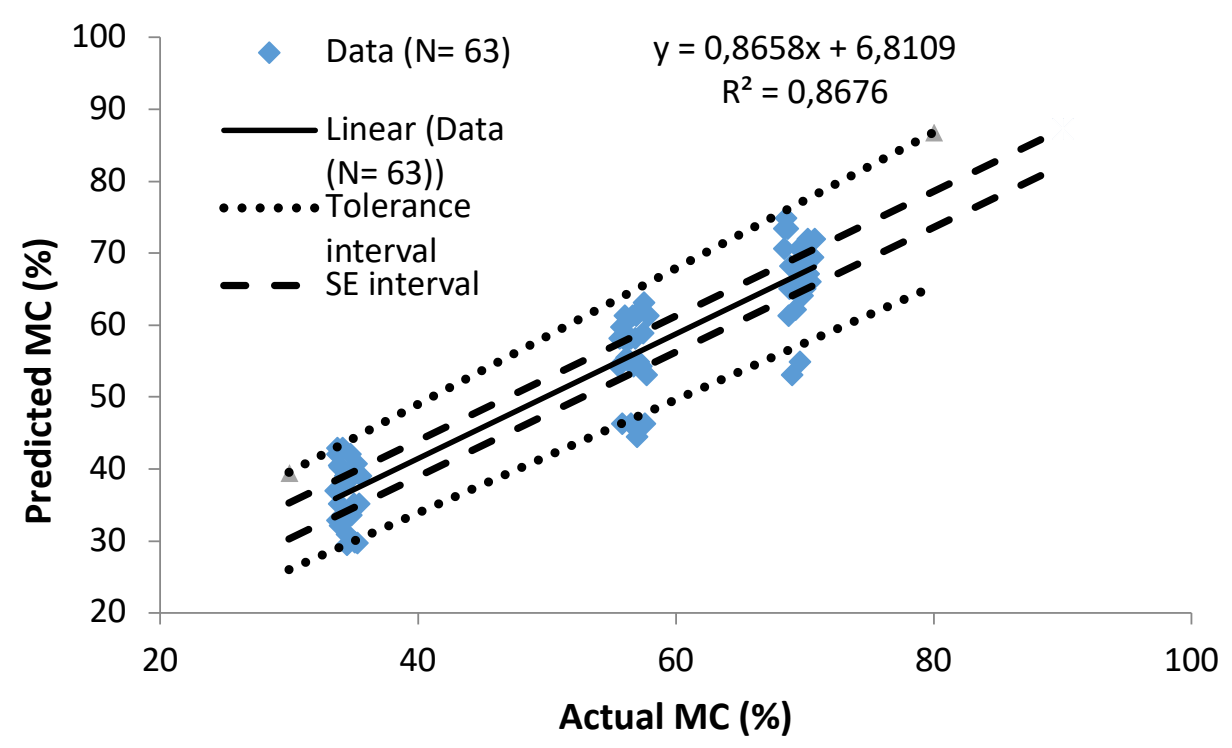

Figure 9. EIS modelling at wood moisture levels above FSP.

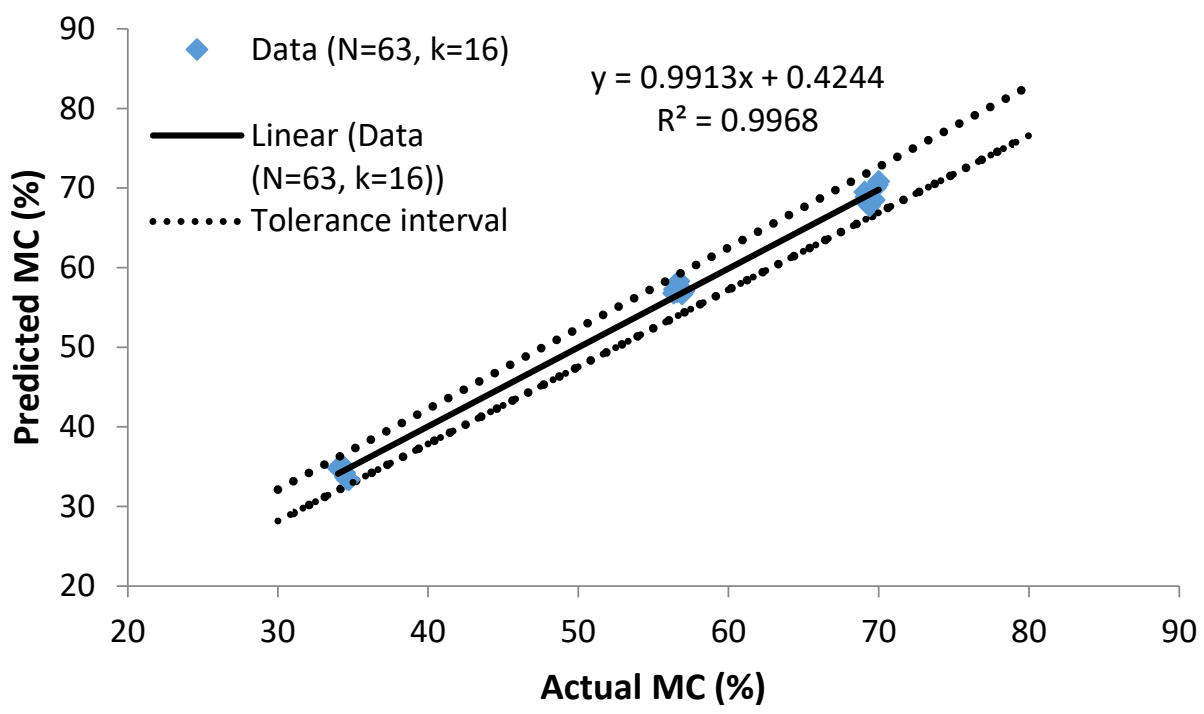

Figure 10. EIS modelling at wood moisture levels above FSP, multiple $(k=16)$ model. 


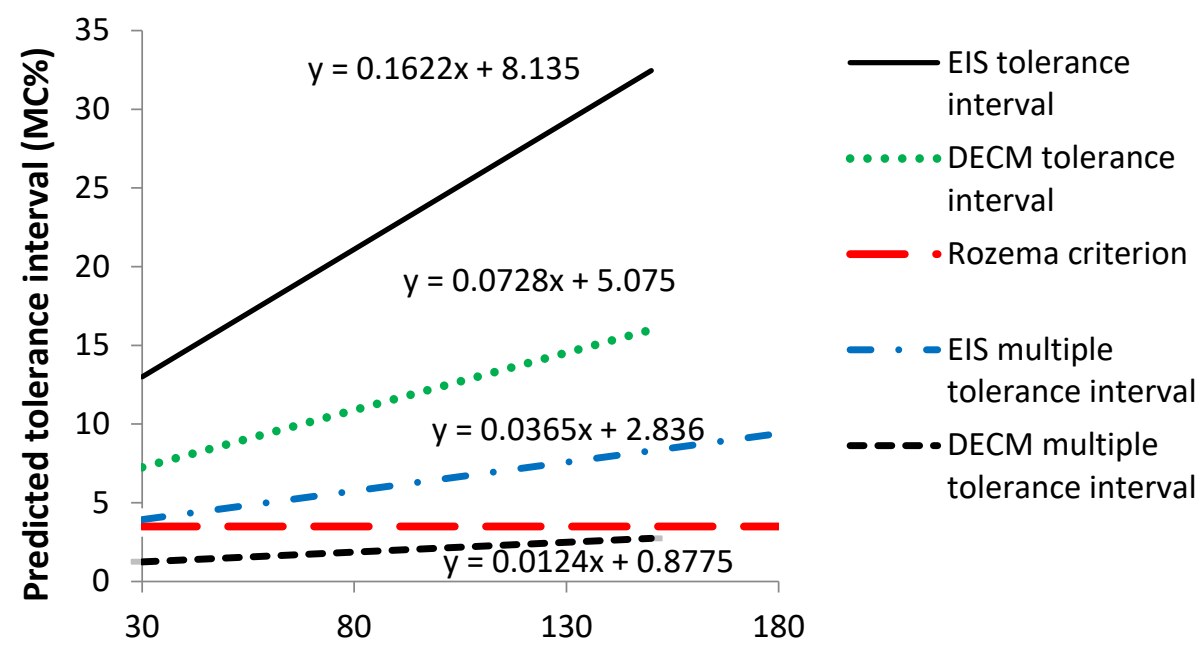

Actual moisture content (MC\%)

Figure 11. Comparison of the tolerance intervals (TI) predicted for single measurements of different models (using formulas in Table 2) and with the Rozema quality criterion at wood moisture levels above FSP. Corresponding graphs of the predicted TI are given from top to bottom as follows: EIS, DECM, EIS multiple, Rozema quality criterion (dashed line, parallel to $x$-axis), and DECM multiple.

terms (Laaneots \& Mathiesen, 2006). Thus, equating the Rozema 3.5\% MC quality criterion with the tolerance interval in this study actually makes the Rozema criterion somewhat more stringent. In Figure 11, the Rozema criterion is marked with a dashed line parallel to the $x$-axis.

In Moschler's paper (2004) it was found that the actual MC point of $28.60 \%$ of the high frequency capacitance method (4.5 to 6.0 GHz) is estimated to have a predicted expanded uncertainty of $\pm 3.62 \%$; thus, the corresponding tolerance interval for this point is $7.24 \% \mathrm{MC}$. In comparison, a tolerance interval of $7.26 \% \mathrm{MC}$ calculated for the same actual MC point of $28.60 \%$ was found in this study for the low-frequency capacitance method (see Table 2, second row), using the relevant formulas. Therefore, the consistency of repeated (reproduced) measurements in different laboratories and under different test conditions is surprisingly good. In another paper (Johansson et al., 2003), an RMSEE of $12.52 \%$ $\mathrm{MC}$ was found for the high-frequency $(9.375 \mathrm{GHz})$ capacitance method for above FSP, and of $0.74 \% \mathrm{MC}$ for below FSP. This study found SE values that were very close to the RMSEE, as is shown in Table 2 (see formulas 6 and 7): above FSP SE it was $4.88 \% \mathrm{MC}$ and below FSP SE it was $0.61 \%$ MC. Thus, below FSP the numerical data are comparable, but above the FSP range, the low-frequency capacitance method used in this study provides results that are twice as good as those achieved with the model residual error.

In our research, comparable experiments for the dielectric capacitance and EIS method were conducted under the same test conditions and for the same tree species (birch). In addition, 16 arithmetic averages in a single series of measurements were modelled in the MC range above FSP. The compared results are presented in Figures 6, 7, 8, 9 and 10 and in Table 2. Figure 11 shows that there is a tendency for the tolerance interval (TI) of a single measurement to increase in proportion to the increase of the actual MC, though the increment is different for each model. The results of the modelling summarized in Figure 11 also show that in the actual MC range (30-150\%), the Rozema quality 
criterion cannot be met either by a single measurement performed with the capacitance method or by a single measurement performed with the EIS method. Using a series of 16 measurements, only the capacitance method can meet the Rozema quality criterion in the actual MC range above FSP (30-150\%), whereas the EIS method fails to do so. However, according to Table 2 (row $5)$, the SE of the EIS method is lower than the Rozema quality criterion $(\mathrm{SE}=0.867)$. Consequently, by increasing the number of measurements $(k)$ to more than 16 , it is likely that the Rozema quality criterion can also be met in the case of the EIS method. The wood moisture meter with the recently patented electric charging effect (polarization-type) may prove promising for use in the harsh climatic conditions of a kiln (Tamme et al., 2020). The patented polarization-type wood moisture meter has basically the same reliability as a conventional resistance-type moisture meter given how it is calibrated, but could meet the Rozema quality criterion with just one measurement based on the modelling results (that is, without the series of 16 repeated measurements) (Tamme et al., 2021).

The reliability of the regression models in Table 2 was verified by the Kolmogorov-Smirnov and Shapiro-Wilk non-parametric test of regression residuals in the program $\mathrm{R}$ environment, in accordance with the methodology used in a previous paper (Tamme et al., 2014). All the models given in Table 2 passed the Kolmogorov-Smirnov test (marked as "K-S" in the table). The DECM (below FSP) and the DECM (above FSP, multiple) passed the more stringent Shapiro-Wilk normality test (marked as "S-W" in Table 2).

\section{Conclusions}

The DECM was found to be less reliable than the EIS method for use in harsh kiln climate. The dielectric capacitance method will require more development in the fu- ture so that it can be reliably (i.e., without the risk of parasitic capacitance and static charges) used in harsh kiln conditions. However, testing of the DECM and the EIS method under the same test conditions and comparing the modelled test results according to the Rozema quality criterion showed that the dielectric capacitance method exhibits higher accuracy in the MC range above FSP. The DECM of low sensitivity to temperature may prove promising in practice, if the purpose is to quickly and reliably determine prior to the start of the drying process the average moisture content of a wood batch for the wood drying simulation program using a non-destructive method.

Acknowledgements. This work was supported by the Environmental Investment Centre of Estonia (Grant No. 16200).

\section{References}

ASTM D4444-08. 2008. Standard Test Method for Laboratory Standardization and Calibration of Hand-Held Moisture Meters. Annual Book of ASTM Standards, West Conshohocken, PA, ASTM International. 10 pp.

BES Bollmann Drying and Control Systems. [WWW document]. - URL https:/ / www.besbollmann.com/. [Accessed 3 March 2021].

Brookhuis Micro-Electronics BV. 2009. Moisture measuring manual Version 1.4. 27 pp.

Brookhuis. [WWW document]. - URL https:// brookhuis.com. [Accessed 3 March 2021].

Casans Berga, S., Garcia-Gil, R., Navarro Anton, A.E., Rosado-Munoz, A. 2019. Novel wood resistance measurement method reducing the initial transient instabilities arising in DC methods due to polarization effects. Electronics, 8(11), 1253. https://www.mdpi. com/2079-9292/8/11/1253/htm.

Feutron Klimasimulation GmbH. [WWW document]. - URL https://www.feutron.de/ en/weathering-chamber/. [Accessed 13 April 2021].

Gann Mess- und Regeltechnik GmbH. [WWW document]. - URL http://www.gann.de. [Accessed 13 April 2021].

ISO 3130:1975. 1975. Wood - Determination of moisture content for physical and mechanical tests. Geneva, Switzerland International Organization for Standardization. 2 pp. 
ISO 3534-1:1993. 1993. Statistics - vocabulary and symbols - part 1: probability and general statistical terms. Geneva, International Organization of Standardization. 53 pp.

James, W.L., Yen, Y.-H., King, R.J. 1985. A microwave method for measuring moisture content, density and grain angle of wood. United States Department of Agriculture. [WWW document]. - URL http://www. treesearch.fs.fed.us/pubs/5792. [Accessed 13 May 2021].

Johansson, J., Hagman, O., Oja, J. 2003. Predicting moisture content and density of Scots pine by microwave scanning of sawn timber. Computers and Electronics in Agriculture, 41(1-3), 85 - 90. https://doi.org/10.1016/ S0168-1699(03)00044-9.

Keithley.2004.Low LevelMeasurementsHandbook 6th Edition, 239 pp. [WWW document]. - URL http:/ / web.mit.edu/8.13/8.13d/manuals / LowLevMsHandbk.pdf. [Accessed 3 March 2020].

Kiviste, A. 1999. Matemaatiline Statistika MS Excel Keskkonnas (Mathematical Statistics in MS Excel Environments). Tallinn, GT Tarkvara OÜ. 86 pp. (In Estonian)

Krause, S. 2003. Impedance methods. - Bard, A.J., Stratmann, M., Unwin, P.R. (eds.). Encyclopedia of Electrochemistry, Vol. 3, Instrumentation and Electroanalytical Chemistry, Weinheim, Wiley-VCH. 196-229.

Laaneots, R., Mathiesen, O. 2006. An Introduction to Metrology. Tallinn, TUT Press. $271 \mathrm{pp}$.

Metrohm Autolab. [WWW document]. - URL http:/ / www.ecochemie.nl. [Accessed 13 April 2021].

Moschler, W. W. 2004. Wireless microwave wood moisture measurement system for wood drying kilns. Final Technical Report, Knoxville, Tennessee. University of Tennessee, 18 pp.

R Core Team. 2010. R: A language and environment for statistical computing. $\mathrm{R}$ Foundation for Statistical Computing, Vienna, Austria. [WWW document]. - URL http://www.rproject.org. [Accessed 13 April 2021].

Rozema, P. 2010. Do`s and don'ts in respect to moisture measurement. - Proceedings of the Final Conference of COST Action E53: The Future of Quality Control for Wood \& Wood Products, UK, 4-7th May 2010. Edinburgh, 9 pp. https://www.napier. ac.uk/ /media/worktribe/output-208736/ e53edinburghproceedingspdf.pdf .

Salin, J.G. 1990. Simulation of the timber drying process. Prediction of moisture and quality changes. - Doctoral thesis. Helsinki, EKONO Oy. 103 pp.

Scanntronik Mugrauer GmbH. [WWW document]. - URL www.scanntronik.de/. [Accessed 13 April 2021].

Stamm, A.J. 1927. The electrical resistance of wood as a measure of its moisture content. Industrial and Engineering Chemistry, 19(9), 1021-1025.
Tamme, H., Tamme, V., Kask, R., Muiste, P. 2019. Non-destructive dielectric method for determining the moisture content of newly sawn timber for moisture content above FSP. - Wang, X., Sauter, U.H., Ross, R.J. (eds.). Proceedings of the 21st International Nondestructive Testing and Evaluation of Wood Symposium. - General Technical Report FPL-GTR-272. Madison, WI: US. Department of Agriculture, Forest Service, Forest Products Laboratory, 213-224.

Tamme, V. 2016. Development of resistance-type control methods for wood drying. - PhD thesis. Tartu, Estonian University of Life Sciences. 135 pp.

Tamme, V., Muiste, P., Kask, R., Tamme, H. 2012. Experimental study of electrode effects of resistance type electrodes for monitoring wood drying process above fiber saturation point. - Forestry Studies / Metsanduslikud Uurimused, 56, 42-55. https://doi. org/10.2478/v10132-012-0004-6.

Tamme, V., Muiste, P., Padari, A., Tamme, H. 2014. Modelling of resistance-type wood moisture meters for three deciduous tree species (black alder, birch, aspen) in moisture contents above fibre saturation point. - Baltic Forestry, 20(1), 157-166.

Tamme, V., Muiste, P., Tamme, H. 2013. Experimental study of resistance type wood moisture sensors for monitoring wood drying process above fibre saturation point. - Forestry Studies / Metsanduslikud Uurimused, 59, 28-44. https://doi.org/10.2478/fsmu-20130009.

Tamme, V., Tamme, H., Bernotas, T., Muiste, P., Olt, J. 2020. Moisture meter and method for measuring the moisture content of wood above the fibre saturation point of a wood with the electric charging effect. Patent No EE 05822B1 Priority: 16.07.2018. [WWW document]. - URL https:// ee.espacenet.com/publicationDetails / biblio? $\mathrm{DB}=\mathrm{EPODOC} \& \mathrm{II}=0 \& \mathrm{ND}=3 \&$ adja cent $=$ true \&locale $=$ ee_EE\&FT $=\mathrm{D} \&$ date $=202$ $00217 \& C C=E E \& N R=201800017 \mathrm{~A} \& \mathrm{KC}=\mathrm{A}$. [Accessed 3 March 2020].

Tamme, V., Tamme, H., Miidla, P., Muiste, P. 2021. Novel polarization-type moisture meter for determining moisture content of wood above fibre saturation point. - European Journal of Wood and Wood Products, 79, 1577-1587. http:/ / link.springer.com/article/10.1007/ s00107-021-01682-6.

Tiitta, M., Savolainen, T., Olkkonen, H., Kanko, T. 1999. Wood moisture gradient analysis by electrical impedance spectroscopy. Holzforschung, 53, 68-76.

Tiitta, M., Tomppo, L., Lappalainen, R. 2010. Combined method for monitoring wood drying process. - Proceedings of 11th International IUFRO Wood Drying Conference, Sweden, 1822 January. Skellefteå, 76-80. 
Uwizeyimana, P., Perrin, M., Eyma, F. 2020. Moisture monitoring in glulam timber structures with embedded resistive sensors: study of influence parameters. - Wood Science and Technology, 54, 1463-1478. https://doi. org/10.1007/ s00226-020-01228-8.

Wavetek Meterman. [WWW document]. - URL https://www.tequipment.net/ WavetekMetermanLCR55.html. [Accessed 13 August 2021].

Welling, J. 2010. Dried timber- how to specify correctly. European Drying Group (EDG), COST E53. 38 pp. [WWW document]. - URL https://businessdocbox.com/ storage/76/74044204/1638107577/ Y3f92J3v0Zn6mj1C96VKOA/74044204.pdf. [Accessed 13 April 2021].
Zuleta, M. 2005. Electrochemical and ion transport characterisation of nanoporous carbon derived from SiC. - Doctoral thesis. Stockholm, KTHRoyal Institute of Technology, Department of Chemical Engineering and Technology. 85 pp. [WWW document]. - URL http://www.divaportal.org/smash/record.jsf?pid=diva2 $\% 3 \mathrm{~A} 7$ 694\&dswid=-1261. [Accessed 13 August 2021]. 


\title{
Puidu niiskussisalduse määramise kahe vahelduvvoolu meetodi katsetamine puidukuivati tingimustes
}

\author{
Hannes Tamme, Regino Kask, Peeter Muiste ja Valdek Tamme
}

\section{Kokkuvõte}

Selles artiklis uuriti kahte erinevat vahelduvvoolu meetodit puidu niiskussisalduse määramiseks. Dielektrilise mahtuvusmeetodi (lühidalt mahtuvusmeetod) korral asetatakse puit, mille niiskussisaldust määratakse, omavahel, ja ühtlasi uuritavast puidust elektriliselt isoleeritud metallplaatide vahele. Moodustub nn. mõõtekondensaator, milles puit täidab dielektriku rolli. Plaatide vahelise elektrimahtuvuse mõõtmiseks rakendatakse plaatidele vahelduvpinge. Puidu niiskussisaldus muudab dielektriku (antud juhul puidu) elektrilisi omadusi, ning seetõttu muutub ka mõõtekondensaatori elektrimahtuvus, mis mõõdetakse ja seostatakse mõõtemudelis ehk kalibreerimismudelis puidu niiskussisaldusega. Teise vahelduvvoolu meetodi, elektrilise impedantsi spektromeetria meetodi korral antakse vahelduvpinge otseselt puitu sisestatud roostevabast terasest või süsinikkiust nõelelektroodidele, ja mõõdetakse puidu elektrilist kogutakistust (impedantsi), seejärel koostatakse vastav mõõtemudel puidu niiskussisalduse määramiseks.

Elektrilise impedantsi spektromeetria ja mahtuvusmeetodi kasutamise võimalusi on üheaegselt üle kiu küllastuspunkti puidu niiskussisaldustel ja puidukuivati karmides kliimatingimustes suhteliselt vähe uuritud. Selle uurimuse raames tehti mahtuvusmeetodi kalibreerimiseks kasutatud mõõtekondensaatori prototüübi töökindluse katsetused puidukuivati karmi sisekliima $\left(50^{\circ} \mathrm{C}\right.$ ja $\left.98 \% \mathrm{RH}\right)$ tingimustes. Uuriti veeauru kondenseerumist mõõtekondensaatori plaatidel, plaatide isolaatorite lekkimist ja staatiliste elektrilaengute tekkimist plaatidel. Mõõtekondensaatori töökindlust häirivate efektide jaoks leiti iga efekti poolt esile kutsutud parasiitmahtuvustele kvantitatiivsed vahemikud. Leiti, et mahtuvusmeetod on puidukuivati karmides kliimatingimustes kasutamiseks vähem töökindel kui elektrilise impedantsi meetod. Samuti modelleeriti võrdlevalt samades katsetingimustes ja sama puuliigi (kask) korral mahtuvusmeetodi ja elektrilise impedantsimeetodi võimalusi etteantud Rozema kvaliteedikriteeriumiga $\pm 1.75 \%$ kasepuidu niiskussisalduse ennustamiseks üle puidu kiu küllastuspunkti niiskussisaldustel. Samades katsetingimustes osutus kasepuidu niiskussisalduse ennustamisel üle kiu küllastuspunkti puidu niiskussisalduste piirkonnas mahtuvusmeetod täpsemaks kui elektrilise impedantsi meetod.

Received August 23, 2021, accepted October 04, 2021 